\title{
LESSONS FROM HISTORY
}

\section{Historical Features Regarding the Neuropathic Outbreaks in Brazilian Troops in the Paraguayan War}

\author{
Marleide da Mota Gomes, Associate professor \\ Institute of Neurology, Federal University of Rio de Janeiro, Rio de Janeiro, Brazil
}

\begin{abstract}
During the Paraguayan War, Brazilian army and navy officers attributed outbreaks of combatant limb weakness with particular features such as tingling to palustrian causes. A dietary basis was not fully suspected at the time, and the popular name beriberi had not been coined. During wartime, there was a shortage in the food supply in addition to poor environmental conditions and diarrheal diseases, and many reports of "palustrian cachexia" were made. There are also reports of the use of native flora to feed troops, as well as alcoholism. There are also accounts of the death of horses with symptoms similar to those of combatants. It was reported that black soldiers were more resistant to "palustrian cachexia." This article presents the disease ecology and clinical manifestations of beriberi at wartime, linked to starvation and consumption of pickled food and native flora. These military explorations and operations in the Paraguayan War happened more than $150 \mathrm{y}$ ago and present some aspects of wilderness medicine in the past.
\end{abstract}

Keywords: beriberi, polyneuropathy, thiamine, thiaminase

\section{Introduction}

The Paraguayan War, which lasted from November 13, 1864, to March 1, 1870, and was initially between Paraguay and Brazil but soon against the Triple Alliance of Brazil, Argentina, and Uruguay, was a regional conflict that became the bloodiest confrontation in Latin America. This long war troubled 4 nations and all soldiers, but mainly the Paraguayan population, which suffered incalculable losses and deprivation. ${ }^{1}$

The Franco-Prussian War (July 19, 1870 to January 28, 1871) started at the end of the Paraguayan War and had some similarities and significant differences. The first hit the center of the country, Paris. In Brazil, the distant and isolated southwest province of Mato Grosso was the hardest hit by the war conflicts; however, to fight against Paraguayan forces, the imperial government located in Rio de Janeiro summoned fighters from all over continental Brazil. ${ }^{2}$ In both wars, the starving population and the combatants were all subjected to lethal infectious diseases. In addition, the logistics of health care were disorganized, especially in the

Corresponding author: Marleide da Mota Gomes, Associate professor, Federal University of Rio de Janeiro: Universidade Federal do Rio de Janeiro; e-mail: mmotagomes@acd.ufrj.br.

Submitted for publication September 2020.

Accepted for publication March 2021. remote Brazilian regions of the battlefield; moreover, anesthesia and antiseptic surgery were in their beginnings. ${ }^{3}$ The distance from the wealthier centers made the feeding and medical care of the troops even more challenging., ${ }^{2,4}$

In times of war, there is an opportunity for the development of new techniques, and further questions arise about diseases that affect combatants. During World War I, for instance, Georges Guillain (1876-1961), Alexandre Barré (1880-1967), and André Strohl (1887-1977) witnessed (1916) 2 cases of soldiers with similar symptoms and signs that are known today as Guillain-Barré syndrome.

In this article, outbreaks of peculiar symptoms of neuropathy in Brazilian soldiers in the Paraguayan War are studied. The original reports and contemporary science did not have the critical clinical elements needed to reach a diagnosis at the time..$^{6-13}$

Vitamin B1 (thiamine) deficiency is called beriberi, and descriptions of the term's origins vary, with some claiming that it means weak movement or "an awful sickness" in the language of natives of what is now Sri Lanka. Currently, the causes and consequences of thiamine deficiency are widely studied and known. ${ }^{14-21}$ Silva Lima $^{13}$ meticulously described the clinical picture of beriberi, establishing the differential diagnosis with pellagra, and recorded anatomopathological data of necropsy. He classified 
beriberi into 3 clinical forms: polyneuritic, edematous, and mixed. Later, the medical literature subdivided it into dry and wet, based on the amount of fluid that accumulates in the body. Many systems aside from the nervous and cardiovascular systems are affected by severe thiamine deficiency, including the gastrointestinal tract. ${ }^{15}$ Several of the cases reported by the primary referred authors $^{7,8,10-12}$ of this article are suggestive of thiamine deficiency, which can represent dry or wet beriberi. The former occurs when the nervous system is involved and features impaired reflexes and symmetrical motor and sensory deficits in the extremities. Another variation of dry beriberi is Gayet-Wernicke's encephalopathy (GWE). Wet beriberi occurs when the cardiovascular system is stricken with heart failure, with or without neuropathy. ${ }^{16}$

Although beriberi was known for millennia in Asia, it became more common in the late 1800s with the increased processing of rice. It was accurately described for the first time in 1629 by the Leiden physician, Jacobus de Bondt, also called Bontius. He reported progressive sensorimotor polyneuropathy. ${ }^{14,17,18}$ Factors postulated at the time to contribute to beriberi comprised poor hygiene, poor sanitation, overcrowding, and high ambient temperatures, all coincident with the Paraguayan War battlefield.

From 1878 to 1882 , a large percentage of Japanese naval personnel experienced beriberi. Kanehiro Takaki, a Japanese surgeon, hypothesized that beriberi was linked to a protein-deficient diet; after changing the rice-based diet, the incidence of beriberi in the navy fell dramatically. ${ }^{18}$ Consequently, the nutritional impact difference of beriberi was more marked throughout the Sino-Japanese War (1894-1895) with sustained barley supplementation in the Japanese navy, but not in the army. The same happened during the Russo-Japanese War (1904-1905). ${ }^{18}$ Another Dutch physician, Christiaan Eijkman, in Java, serendipitously recognized dietary factors as a significant cause of "chicken polyneuritis." In this way, he demonstrated that beriberi is the result of a meager diet. His findings led to the discovery of antineuritic vitamins, "anti-beriberi factor" (1897), and "Together with the biochemist Frederick Hopkins who identified certain 'accessory factors' (1906), Eijkman received the Nobel Prize for Physiology or Medicine (1929) for the discovery of vitamins."

In this article, to establish a retrospective diagnosis, several scenarios describing neuropathic outbreaks affecting Brazilian troops are retrieved and scrutinized.

\section{Study Methodology and the Chief Information Collected}

This project was carried out by a physician aiming to make a retrospective diagnosis of the epidemic experienced by
Brazilian troops on the front of the Paraguayan War. This was done mainly by reviewing compelling observations made by Brazilian scholar officers and observers at the time, in addition to academic studies originating from the Escola Tropicalista Baiana (Figure 1). The first testimony came from Alfredo Maria Adriano d'Escragnolle Taunay (1843-1899) (Figure 2), an aristocrat, writer, military officer, and politician of the Brazilian empire, who was a member of the Commission of Engineers of the Expeditionary Corps that went to the province of Mato Grosso. ${ }^{2,6}$

Another officer, Carlos Frederico dos Santos Xavier Azevedo, made reports that are important because they come from a physician versed in the medical literature of the time; his reports address the privations of sailors, ${ }^{7}$ to be compared with Taunay's reports on infantry fighters. ${ }^{8-11}$ Regarding the Tropicalista School, José Francisco da Silva Lima, a Brazilian born in Portugal, published communications on beriberi in the pages of Gazeta Médica da Bahia, under the title "Contribution to the history of a disease that currently reigns in Bahia, in epidemic form, characterized by paralysis, edema, and general weakness." ${ }^{12,13}$ In 1872, these communications were published as a book entitled Essay on Beriberi in Brazil, ${ }^{13}$ but this study was carried out far from the war front.

Here, the most considerable interest is in the 21 st issue published in 1867, which gathers some officers' depositions published in newspapers about what occurred at the front regarding a disease similar to that Silva Lima had been studying. ${ }^{12}$

\section{Scenarios}

The first struggle the Brazilian military force faced was precarious sanitary conditions and hygiene, in addition to hunger. All predisposed the combatants to smallpox, "typhoid fever, and cholera, as well as other mysterious diseases, such as those which affected the nervous system, including 'tetanus which developed in large numbers in the army's wounded' as quoted by Azevedo." "7 Based on the reports of these situations, their probable diagnoses are estimated in the next section.

To begin, it is realized that sailors and soldiers were frequently weak and unwell even before battles. The same author ${ }^{7}$ reiterates the precarious conditions experienced by the combatants:

for the most part, on the insufficiency and low quality of food, on the bad water, on the action of humidity, heatstroke, lack of air renewal, conservation of wet clothes, applied to the body, and lack of cleanliness, ... resulting in illnesses, which significantly abate the forces, and exhaust the 

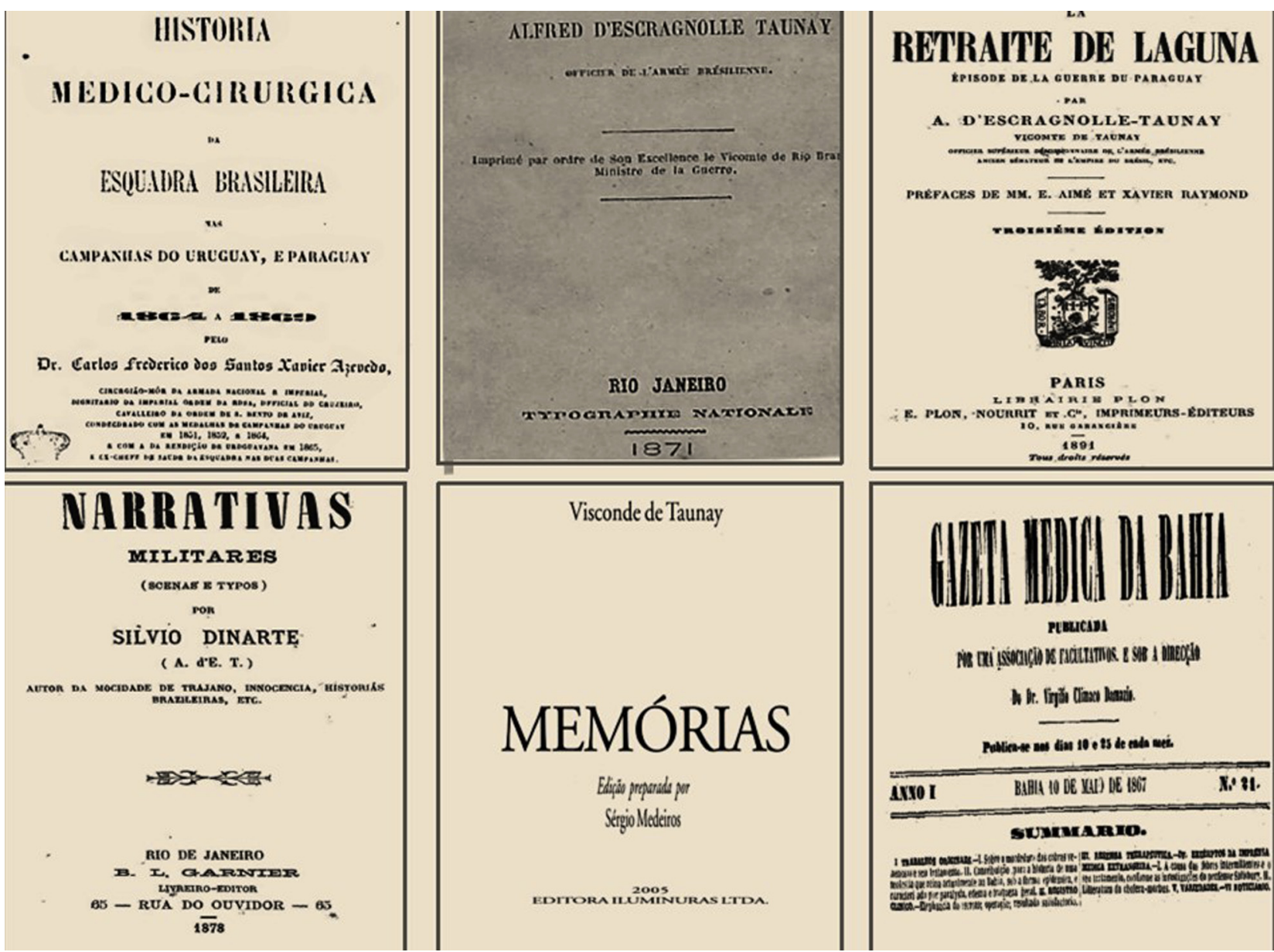

Visconde de Taunay
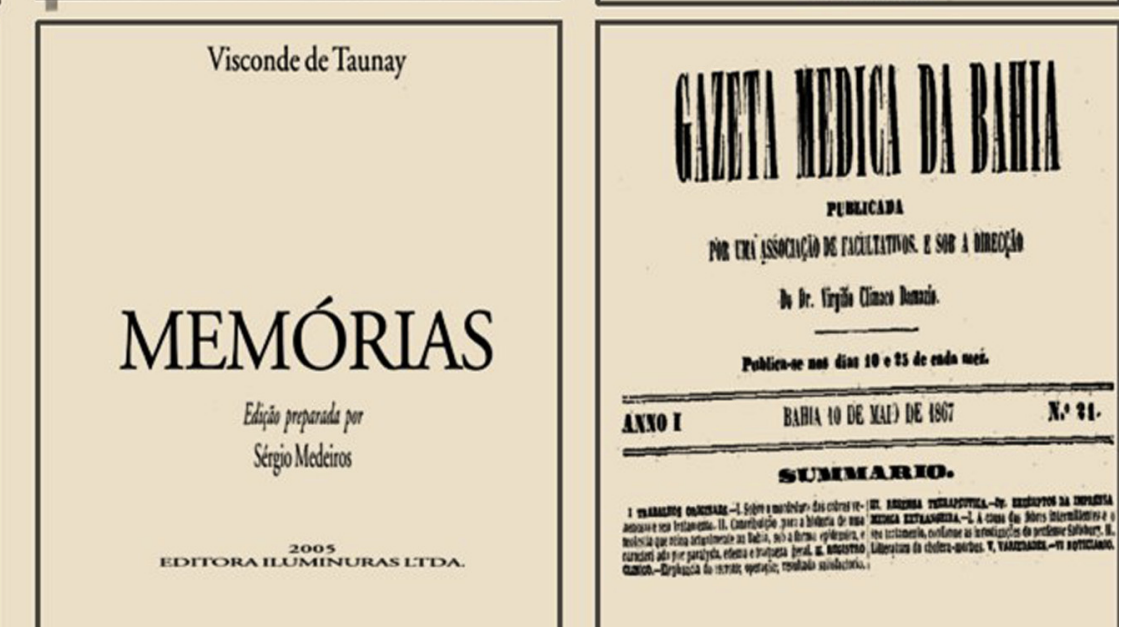

Figure 1. Primary sources of consultation on episodes of muscle weakness and paraesthesia experienced by Brazilian combatants. Carlos Frederico dos Santos Xavier Azevedo published (1870) the book Medical-Surgical History of the Brazilian Police in the Campaigns in Uruguay and Paraguay from 1864 to 1869 . $^{7}$ Taunay published several accounts about the war; the most expressive, regarding medical aspects, are presented here, which include La Retraite de Laguna (1871), ${ }^{10}$ Military Narratives: Scenes and Types (1878), ${ }^{8}$ and Memórias do Visconde de Taunay ${ }^{11}$ (posthumous). José Francisco da Silva Lima and his publications in the Gazeta Médica da Bahia about beriberi (issue published in 1867). ${ }^{12}$

individual, who, continually exposed to the action of the same causes, it acquires a remarkable predisposition for scurvy.

The use of pickled food was very common in the navy, but in its absence, combatants were forced to eat native foods; this was more common among terrestrial combatants. ${ }^{7}$ When the fighters lacked food, they had to eat what they found available in the region, and frequently the water was not drinkable; as a result, soldiers were not only in need of food but also of water supply, as is reported in Azevedo's book. Taunay ${ }^{11}$ also notes the report of resource shortages: "Such a shortage of food, and such a desperate state had arrived, that the general diet was almost exclusive of forest fruits, especially jatobá, whose abundance had taken providential visions." The same author, in his other book published in $1878,{ }^{8}$ emphasized that

Jatobá pods and coconuts were the exclusive food of almost 3,000 people for eight tremendous and endless days... Two more engineers, Ghichorro and Fragoso, threw themselves ... to seek a way out of such a horrible situation and were unable to achieve anything. They fell back; both attacked with beriberi, one never to get up, another healthier having to seek two months later on prompt withdrawal the only way to escape death.

The troops were astonished by the new ailments, as reported by Silva Lima, ${ }^{12}$ "a new obstacle, and perhaps invincible, before them it is faced. An epidemic was entirely unknown in Brazil. More daring and reckless 


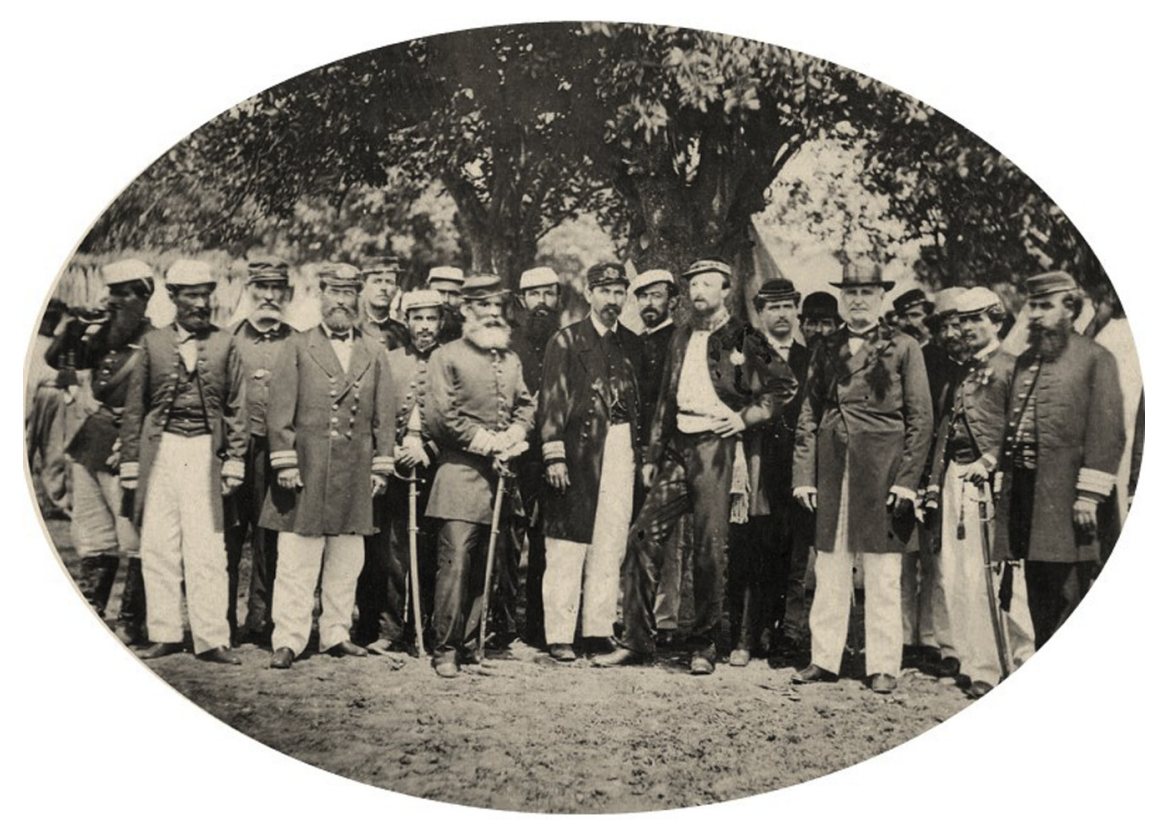

Figure 2. Alfredo d'Escragnolle Taunay (1843-1899) is on the left side of Prince Gastão de Orleans (1842-1922), son-in-law of Emperor Pedro II and General in Chief of the Brazilian Armies (with his hand at his waist), and other Brazilian officers and authorities who participated in the Paraguayan War. Credit: Biblioteca Digital da Fundação Biblioteca Nacional.

than morbus cholera, it blows up like a destructive volcano in the middle of the camp."

The Expeditionary Force did not recognize the new clinical manifestations that affected the combatants during wartime, which were collectively called "Symptoms of palustrial cachexia."7 The author of the Retraite Lagune ${ }^{9}$ calls this strange disease the "Climacteric epidemic of a new species, reflex paralysis." These symptoms were also called gaiters, as reported by the same author in another book, Memorias ${ }^{11}$ : "the gaiter epidemic worsened [popular name the soldiers used to describe beriberi, for the characteristic hardness of the legs, excluding the calves, at the beginning of the disease]."

Soon, however, the troops recognized the syndrome that Taunay ${ }^{11}$ described in such terms:

Then an evil of origin began to appear and marches until then unknown. It attacked in different ways, but always severe if not deadly, sometimes perfidiously and slowly, sometimes with sudden and more terrifying and cruel symptoms, bringing more or less generalized paralysis.

More particularly, the author of Memorias ${ }^{11}$ describes the hallmark polyneuropathy: "he saw Carvalho that had dawned with his feet and legs very swollen, trapped and numb, as well as painful tingling in his hands."

Taunay, in his memoir ${ }^{11}$ published decades after the war, referred to the term beriberi several times but mostly related to the climate: "how not to catch beriberi in such conditions?"; "There the unfortunate column was subjected to the devastation of beriberi"; "In this case, beriberi took the simply paralytic form without any swelling"; "In Coxim, the terrible epidemic began - the plague of chairs - nothing more, nothing less than the beriberi of the mules"; "the beriberi that had not yet been spoken of in all of Brazil and which has become so well known today, without losing, however, the character of gravity that distinguishes it."

Such symptoms were also described by many other writers to newspapers in such terms as "They start by swelling their feet, their legs have weakened, and death follows soon. Some officers walk on a crutch" and "Many officers had left sick, and some had died on the way. As soon as swelling in the legs appears, it is a rarity to escape. The people who resist the most are those of color," as reproduced by Silva Lima. ${ }^{12}$ Silva Lima continued to present these reports: "the famous paralysis that until the last date had already caused 30 victims among the officers ... who had marched from Coxim." Furthermore, in Memorias, ${ }^{11}$ concerning the association of symptoms and the evolution of the disease, the author affirms that

Sometimes the patient would accuse tingling in the soles of his feet and difficulty in walking, feeling that these signs worsen during the day; to which oppressions, dyspnea, after 
all, the agony and death came; others, it all ran over, and soon passed away who, just before, had been strong and healthy.

Taunay ${ }^{11}$ also differentiated the forms of this neuropathy: "it took the simply paralytic form without any swelling, on the contrary drying out day by day, so that it looked like a hinged doll." He emphasized the lethality of the disease and the importance of environment: "However, the mortality from the leg was still high, and as the doctors had finally concluded that the change of air became the only means to shorten the march of such a singular disease."

Taunay ${ }^{11}$ also highlighted the ignorance the doctors of the time about the nature of this clinical picture: "We certainly found our colleague very badly, almost hampered by any movement due to paralysis. They treated him disorderly, with no plan made, nor logical medication." Again, he ${ }^{11}$ reiterates the doctors' perplexity at the time about this clinical configuration and its treatment: "The doctors, quite ignorant, by the way, were astonished and dared not decide anything, prescribing erratically and with inconsistency and lack of logic worthy of regret."

Reports by the navy doctor ${ }^{7}$ indicate that the navy did not have more knowledge than the ground forces. They too included cases of probable peripheral neuropathy as palustrial cachexia and scurvy:

The symptoms of palustrial cachexia and rheumatism are all diverse, as can easily be seen, and we agree with our distinguished colleague that scurvy may manifest itself in different ways, simulating this or that disease, we cannot, however, admit that these diseases were not accompanied by scurvy symptoms, which they never observed in the cases, which presented themselves. Having studied the malarial fevers, which we are concerned with, we see that palustrial cachexia is a consequence of these complex pyrexias, having different characters, and which are so common in swampy countries, in filthy rivers, in different climates.

The same navy doctor ${ }^{7}$ also associated malaria with palustrial cachexia, as a multifactorial result:

The continuous attacks of fevers were followed by palustrial cachexia, which was characterized by other accidents, such as anemia, edema of the face, and lower limbs, neuralgic pain of the limbs, and trunk increased volume of the spleen, and liver, difficulty in respiratory function, chest and abdominal spills, vomiting, delirium in some cases, and finally death when cachexia had already made significant progress. After the autopsy of the serviceman, who succumbed to palustrial cachexia, the following changes were noted: congestion of the spleen and liver, serous effusions, distending the pericardium, lung edema, abdominal effusion, and injection of the meninges.

\section{Evaluation of the Diagnostic Etiological Hypothesis}

The clinical picture repeatedly described by Taunay and Silva Lima was one of tingling, paralysis, and edema, mainly of the lower limbs. However, it was poorly defined by Azevedo and was generally reported as "Symptoms of palustrial cachexia" and as mixed with scurvy symptoms. ${ }^{7}$ Only in the reissue of Retraite de Laguna $^{9}$ did Taunay recognize the manifestations as those of beriberi, although he still related them to malaria: "This malaria-related disease is known in Brazil under the name beriberi." 9

Interestingly, Taunay ${ }^{9,10}$ related the manifestations to those seen in horses: "we no longer had horses: they had all been removed, in the district of Miranda, by an epizootic of the kind of reflex paralysis which had so cruelly tested us ourselves." Indeed, thiamine deficiency is uncommon in the horse but can occur when the animal eats bracken fern that contains a compound that inhibits the activity of thiamine. ${ }^{17}$

As for genetic predisposition, Silva Lima ${ }^{12}$ notes that "The people who resist the most are those of color," black or indigenous. Notably, black soldiers belonged to a lineage of human trafficking survivors from Africa or may have had some personal food strategy; it is less likely that the selectivity of involvement was due to genetic factors-that is, due to rare pathogenic mutations in genes that encode enzymes and transporters involved in thiamine metabolism. ${ }^{15}$ The latter is less convincing owing to the heterogeneous ethnicity of the Brazilian population.

There are also many accounts that Brazilian combatants, as a result of the shortage of supplies, made use of native vegetables and fruits. Taunay ${ }^{8}$ reported that jatobá pods and coconuts were the exclusive food of almost 3000 people for 8 vast and endless days. It should be noted that the jatobá tree (Hymenaea courbaril L.) is used extensively for its hardwood and its seed pods for food. It can be eaten raw or roasted. ${ }^{22}$ However, consumption of other toxic native food cannot be ruled out, and some can promote thiamine deficiency. An example is the disastrous trans-Australian Burke-Willis exploratory expedition of 1860-1861. This is an example of an endogenously induced thiamine deficiency and consequent beriberi experienced by the explorers, who were desperate with hunger. They started to eat nardoo, a flour prepared from 
the sporocarp of the nardoo fern (Marsilaea drummandi); this plant contains a large amount of thiaminase I, even more than the fronds of bracken fern, which cause the "staggers" in horses and sheep. Thiaminase, in large quantities, soon depletes the thiamine in the body. ${ }^{17}$

It is essential to emphasize the extensive use of cassava in Brazil. Cassava can be harmful if underprocessed, which may have happened among Brazilian troops in times of food limitation. Furthermore, a diet with polished rice or cassava as a staple may induce thiamine deficiency. ${ }^{20}$ Concerning cassava, Arlindo de Assis, the first Brazilian to publish experimental studies of beriberi, "obtained polyneuritis with the cassava flour commonly used in Brazil," apud Rodrigues Figueiredo. ${ }^{23}$ A century later, in an endemic area of Nigeria, Osuntokun defined the occurrence of ataxic polyneuropathy that has been attributed to exposure to cyanide from cassava foods. ${ }^{24}$

In addition, pickled food was frequently used in the navy, according to Azevedo. This raises the suspicion of the presence of sulfites added to foods, usually as a preservative. ${ }^{19}$ Azevedo also talks about the ample use of alcohol by the combatants, in medicines as well as by ingestion. Likewise, he claims that "drunkenness, producing serious illnesses, maximum in hot countries, compromised nutrition." "Moreover, there is a record that "a large quantity of hooch (aguardente) circulated in the camps," as recorded by Dourado. ${ }^{4}$ The nervous system may be damaged by alcohol, either through its direct action or its derivatives. Vitamin deficiencies associated with alcoholism and other causes are eventually connected to the failure of vital organs, such as the liver. Notably, the mechanisms hypothesized for GWE and ethyl polyneuropathy are both direct alcohol toxicity and a deficiency, in particular of thiamine. ${ }^{25}$

Bruyn et $\mathrm{al}^{7}$ reinforce the idea that beriberi has rarely been reported in Latin America, one of the few exceptions being the report by Silva Lima of an outbreak of beriberi in $1866-1868 .{ }^{13}$ In the face of so many uncertainties, it is easy to understand why Taunay and his translators insisted on an infectious etiology of beriberi instead of nutritional deficiency during wartime. This error persisted in the Brazilian historical records regarding the Paraguayan War. At the beginning of the 20th century, cases of beriberi in Mato Grosso and Amazon were considered by the locals as a "quinine-resisting form of paludism," as quoted by Lindsay. ${ }^{26}$

It is possible to affirm that the patients described by Taunay and the officers' letters published in newspapers, with ideas reproduced by Silva Lima, resembled those studied by Silva Lima in Bahia, Brazil, far from the war front. $^{12}$
Now, we may conclude that the main etiological suspicion of the frequently reported polyneuropathy was caused by thiamine. Thiamine deficiency typically presents with peripheral or central neurological symptoms, the latter commonly known as GWE.

\section{Conclusions}

We reach a diagnosis of beriberi, both dry and wet types, during the Paraguayan War as the cause of the epidemics of sensorimotor polyneuropathy presenting with symptoms and signs of dysesthesia, limb weakness, and edema. The multifactorial risk factors, mainly related to thiamine deficiency, include food with low thiamine levels or meals containing thiaminase or thiamine antagonists, in addition to alcoholism.

Acknowledgments: The author expresses sincere gratitude to Prof. Marcos Raimundo Gomes de Freitas, peripheral neuropathy specialist, for reading a version of this paper and giving valuable suggestions for the improvement of the work.

Financial/Material Support: None.

Disclosures: None.

\section{References}

1. Bethell L. The Paraguayan War (1864-70). In: Brazil: Essays on History and Politics. London, UK: School of Advanced Study, University of London, Institute of Latin American Studies; 2018.

2. Sabioni ACS. Voluntários da pátria na guerra do Paraguai: a epopéia do $17^{\circ}$ corpo de Minas Gerais. trabalho de conclusão do Curso de Especialização em História Militar, da Universidade do Sul de Santa Catarina, como requisito parcial para obtenção do título de Especialista em História Militar. Orientador: Prof. Carlos Roberto Carvalho Daróz. Ouro Preto, 26 de Setembro de 2017.

3. Gomes MM. France's "année terrible" of the Franco-Prussian War and Paris Commune, 150 years ago, and some remarkable neurologists at the time. Rev Bras Neurol. 2019;55(4):18-24.

4. Dourado MTG. A História esquecida da Guerra do Paraguai: fome, doenças e penalidades. Doutorado em História Social pela Universidade de São Paulo; 2010.

5. Gomes MM. French school and World War First: neurological consequences of a frightening time. Arq Neuropsiquiatr. 2015;73(5):463-5.

6. Maretti MLL. O Visconde de Taunay e os fios da memória. 29-30. São Paulo: Editora UNESP; 2006.

7. Azevedo CFSX. História Médico-Cirúrgica da Esquadra Brasileira nas Campanhas do Uruguai e Paraguai. Rio de Janeiro: Tip. Nacional. 1870;126:132, 164, 171, 409, 482.

8. Taunay AE (Silvio Dinarte). Narrativas militares: scenas e typos. Rio de Janeiro: B.L. Garnier; 1878:49.

9. Taunay AE. La Retraite de Laguna. Paris: Librairie Plon E. Plon, Nourrit et Cie, Imprimeurs-Éditeurs; 1891;6:46. 
10. Taunay AE. La Retraite de Laguna. Rio de Janeiro: Tip. Nacional; 1871:52.

11. Taunay AE. Memórias do Visconde de Taunay. Edição preparada por Sergio Medeiros. São Paulo: Iluminuras; 2004;278,286-8, 291, 292, 298.

12. Silva Lima JF. "Contribuição para a história de uma moléstia que reina atualmente na Bahia, sob a forma epidêmica, e caracterizada por paralisia, edema e fraqueza geral." Gazeta Médica da Bahia. 1867;I(21):243-5.

13. Silva Lima JF. Ensaio sobre o beriberi no Brazil. Bahia: Livrarias de JB Martin, Caulina EC e Viuva Lemos; 1872;9-22(68-70):95-6.

14. Lanska DJ. Chapter 30: historical aspects of the major neurological vitamin deficiency disorders: the water-soluble B vitamins. Handb Clin Neurol. 2010;95:445-76.

15. Dhir S, Tarasenko M, Napoli E, Giulivi C. Neurological, psychiatric, and biochemical aspects of thiamine deficiency in children and adults. Front Psychiatry. 2019;10:207.

16. Shible AA, Ramadurai D, Gergen D, Reynolds PM. Dry beriberi due to thiamine deficiency associated with peripheral neuropathy and Wernicke's encephalopathy mimicking Guillain-Barré syndrome: a case report and review of the literature. Am J Case Rep. 2019;20:330-4.

17. Bruyn GW, Poser CM. The History of Tropical Neurology: Nutritional Disorders. Science History Publications/USA. 2003;1:14.
18. Department of Natural Resources. Vitamin B1 (thiamine) deficiency. Available at: http://thiamine.dnr.cornell.edu/. Accessed September 1, 2020.

19. Department of Natural Resources. Causes of thiamine deficiency. Available at: http://thiamine.dnr.cornell.edu/ Thiamine_causes.html. Accessed September 1, 2020.

20. Whitfield KC, Bourassa MW, Adamolekun B, Bergeron G, Bettendorff L, Brown KH, et al. Thiamine deficiency disorders: diagnosis, prevalence, and a roadmap for global control programs. Ann N Y Acad Sci. 2018;1430(1):3-43.

21. Calderón-Ospina CA, Nava-Mesa MO. B vitamins in the nervous system: current knowledge of the biochemical modes of action and synergies of thiamine, pyridoxine, and cobalamin. CNS Neurosci Ther. 2020;26(1):5-13.

22. Tonini H, Arco-Verde MF. O jatobá (Hymenaea courbaril L.): crescimento, potencialidades e usos. Empresa Brasileira de Pesquisa Agropecuária (EMBRAPA); 2003.

23. Rodrigues F. Beriberi experimental e Beriberi humano, com especial referencia às fórmas observadas no Amazonas. Mem Inst Oswaldo Cruz. 1919;11(1):90-120.

24. Osuntokun BO. An ataxic neuropathy in Nigeria. A clinical, biochemical and electrophysiological study. Brain. 1968;91(2):215-48.

25. Fouarge E, Maquet P. Neurological consequences of alcoholism. Rev Med Liege. 2019;74(5-6):310-3.

26. Lindsay JW. Some observations on Brazilian Beriberi. Trans R Soc Trop Med Hyg. 1917;10(5):89-93. 